\title{
Genetic Diversity among Rice Yellow Stem Borer, Scirpophaga incertulas Revealed Using ISSR Markers
}

\author{
Rudraksh Shovan Panda*, Lambodar Behera and Sarat Chandra Sahu
}

National Rice Research Institute, Cuttack-753006, Odisha, India

*Corresponding author

\section{A B S T R A C T}

\section{Keywords \\ Genetic variability, ISSR, Yellow stem borer \\ Article Info \\ Accepted: \\ 04 March 2018 \\ Available Online: \\ 10 April 2018}

Rice Stem borer is an important rice pest in India. In the present study, the genetic variability was analyzed among geographically isolated populations of rice yellow stem borer (YSB) from sixty locations of Odisha using ISSR marker technique. Fifty ISSR primers were screened and eleven ISSR primers were selected on the basis of clarity, usability, and reproducibility of their banding patterns. The 11 primers produced a total of 67 bright and discernible bands, all of which were polymorphic. Three unique bands were identified which will be useful for developing diagnostic markers. Genetic similarity among YSB populations varied from 0.02 to 0.1 , indicating that wide genetic variation exists among YSB populations at molecular level. Most of the populations could be uniquely distinguished from each other and grouped into four major clusters at $20 \%$ level of genetic similarity.

\section{Introduction}

Rice (Oryza sativa L.) is one of the most important staple food crops which feed more than 3 billion people. It has been estimated that more than 200 million tons of rice are being lost annually due to insect pests (Khan et al., 1991). Among different stem borers, yellow stem borer (YSB), Scirpophaga incertulas shares more than 70 percent of total stem borer population. YSB is distributed mainly in Southeast Asia, China, Afghanistan and India. Grain yield losses of 3 to $95 \%$ due to yellow stem borer (YSB) damage have been reported in India (Muralidharan and Pasalu, 2006). It attacks rice throughout its growth period from the seedling stage to maturity. At the vegetative stage, the larva can damage the tillers causing dead hearts, in which the young tiller and leaves of the tiller turn brown and die. During the reproductive stage, injury to tillers can destroy the panicles resulting in whiteheads. This specialist species, $S$. incertulas is the most destructive and dominant species of rice crop in Odisha, India. An estimate made at Central Rice Research Institute (CRRI), Cuttack suggests that everyone per cent increase in stem borers incidence at the vegetative phase registered a loss of 0.28 per cent in yield which at heading stage was shown 0.62 per cent. The potential losses of 40-50 per cent stems before harvest have been estimated due to yellow stem borer alone (Israel and Abraham, 1967). For effective pest management, understanding genetic diversity of insect pest is a 
prerequisite. Development in molecular markers provides a great opportunity for quick and reliable estimation of genetic diversity.

Inter simple sequence repeats (ISSR) are one such marker system which has been extensively used for genetic analysis of plants and animals (Zeitkiewicz et al., 1994; Reddy et al., 1999b; Bornet et al., 2002; Vijayan, 2006). Further, the technique of ISSR amplification is sensitive enough to differentiate closely related individuals (Zietkiewicz et al., 1994) and assess the genetic diversity in germplasm (Wolfe et al., 1998). ISSRs are presumably noncoding loci and are dispersed throughout the genome. In this study we describe the use of ISSR markers to evaluate the extent of genetic relationships and richness among 60 YSB populations of Odisha, India.

\section{Materials and Methods}

\section{Insect materials}

The female moths of yellow stemborers (YSB) were collected from sixty different locations in Odisha (Table 1) and were preserved in 95 per cent ethanol at $4^{0} \mathrm{C}$ for genomic DNA isolation.

\section{Insect DNA isolation}

Female moths of yellow stem borers were used for isolation of genomic DNA (Anonymous, 1993). Single adult female was soaked in $50 \mu$ l of extraction buffer for 10 minutes and then homogenized in $1.5 \mathrm{ml}$ of eppendorf tube with sterilized polypropylene pestle gently and thoroughly and washed with $350 \mu \mathrm{l}$ of extraction buffer. Ten microliter of proteinase-K $(10 \mathrm{mg} / \mathrm{ml})$ was added, mixed well and incubated at $37^{\circ} \mathrm{C}$ for $1 \mathrm{hr}$ followed by addition of $400 \mu \mathrm{l}$ of equilibrated phenol. The samples were centrifuged at $12000 \mathrm{rpm}$ for 10 minutes. The upper layer was carefully transferred to another tube and an equal volume containing $200 \mu \mathrm{l}$ of phenol and $200 \mu \mathrm{l}$ of chloroform: isoamyl alcohol (24:1) was added, mixed well and the solution was centrifuged at $12000 \mathrm{rpm}$ for 10 minutes. Then the supernatant was transferred to a new tube and ten microliter of RNAase $(10 \mathrm{mg} / \mathrm{ml})$ was added and incubated for $1 \mathrm{hr}$ at $37^{\circ} \mathrm{C}$ followed by addition of $400 \mu \mathrm{l}$ chloroform: isoamyl alcohol(24:1) mixed by brief vortexing and centrifuged at $12000 \mathrm{rpm}$ at $40^{\circ} \mathrm{C}$ for 10 minutes. The upper aqueous layer was carefully transferred to another Eppendorf tube and to it $10 \mu \mathrm{l}$ of $\mathrm{NaCl}(5 \mathrm{M})$ and twice the volume of ice cold absolute alcohol was added. An overnight incubation was carried out at $-20{ }^{\circ} \mathrm{C}$ followed by centrifugation at $12,000 \mathrm{rpm}$ for 10 minutes. The DNA pellet was washed with $100 \mu \mathrm{l}$ of 70 per cent ethanol, dried at room temperature and dissolved in 50 $\mu l$ of TE buffer. The quality and quantity of DNA were estimated electrophoretically using $\lambda$ DNA as standard, and stored at $-20{ }^{\circ} \mathrm{C}$ for further analysis.

\section{PCR amplification and agarose gel electrophoresis}

A total of 50 ISSR primers developed by the University of British Columbia Biotechnology Laboratory (www.biotech.ubc.ca) were initially screened, and the 11 primers that produced bright, clear, and reproducible fragments were utilized for further study (Table 2). Each $20 \mu 1$ of PCR reaction mixture Consisted of 25ng of genomic DNA, 1X PCR buffer $\{75 \mathrm{mMTris}-\mathrm{HCl}(\mathrm{pH} 9.0), 50 \mathrm{mMKCl}$, $\left.20 \mathrm{mM}\left(\mathrm{NH}_{4}\right)_{2} \mathrm{SO}_{4}\right\}, 200 \mu \mathrm{M}$ dNTP mix (MBI Fermantas, Lithuania, USA), 5 pmol of primers, $2 \mathrm{mM}$ of $\mathrm{MgCl}_{2}$ and $1 \mathrm{U}$ of TaqDNA polymerase (Biotools, Spain).

Amplification was carried out in a thermal cycler (Perkin Elmer, Cetus, USA), with initial denaturation temperature of $93^{\circ} \mathrm{C}$ for $2 \mathrm{~min}$ followed by 44 cycles of $93^{\circ} \mathrm{C}$ for $1 \mathrm{~min}, 36^{\circ} \mathrm{C}$ 
for $1 \mathrm{~min}$ and $72^{\circ} \mathrm{C}$ for $2 \mathrm{~min}$ and final extension at $72^{\circ} \mathrm{C}$ for 5 minute. The amplified products were size fractionated on a 1.5 per cent agarose gel containing ethidium bromide. The gel was visualized under UV using Gel Imaging System (Fluor Chem TM 5500, Alpha Innotech, USA). PCR amplification with each primer was carried in two replicators.

\section{Data scoring and statistical analysis}

Since ISSR markers were dominantly inherited, each band was assumed to represent the phenotype at a single biallelic locus (Williams et al., 1990). Only bright and discernible fragments across all the population samples were included in the statistical analysis.

ISSR bands were scored as present (1) or absent (0) in agarose gels and entered into a binary matrix representing the ISSR profile of each population. Initially, the potential of ISSR markers for estimating genetic variability of YSB were examined by measuring the marker informativeness through the counting of bands. The bands were counted as: total number of amplified bands (TB); number of polymorphic bands (PB), i.e. bands that were not amplified in all population; number of unique bands (UB), i.e. bands amplified in single population.

To analyze the suitability of ISSR markers to evaluate genetic profiles of YSB, the performance of the markers was measured using four parameters: polymorphic information content (PIC), heterozygosity $(\mathrm{H})$, marker index (MI) and resolving power (RP).

\section{Polymorphic information content (PIC) and Heterozygosity (H)}

The PIC value as well as the $\mathrm{H}$ value for each locus was calculated using the polymorphism information calculator i.e. PICcalc: an online program to calculate polymorphic information content for molecular genetic studies developed by Nagy et al., 2012 (http://w3. georgikon.hu/pic/english/default.aspx).

\section{Marker Index (MI)}

The marker index (MI) was calculated as described by Smith et al., (1997) and Lu* bberstedt et al., 2000: Marker indices were calculated as the product of PIC and the number of polymorphic bands per assay unit (POL)

\section{$\mathrm{MI}=\mathrm{POLxPIC}$}

\section{Resolving Power (RP)}

The resolving power (RP) of each primer was calculated according to Prevost and Wilkinson 1999: $(\mathrm{Rp})=\Sigma \mathrm{Ib}$, where Ib represents the informative fragments. The $\mathrm{Ib}$ can be represented on a scale of $0-1$ by the following formula:

$1-\{2 x(0.5-P i)\}$ where $p$ is the proportion of populations containing the band.

\section{Similarity coefficient}

Data were analysed to obtain Jaccard (1908) coefficients among the populations by using NTSYS-pc version 2.11W (Rohlf 1997). The SIMQUAL program was used to calculate the Jaccard's coefficients.

A common estimator of genetic identity and was calculated as follows: Jaccard's coefficient $=N \mathrm{AB} /(N \mathrm{AB}+N \mathrm{~A}+N \mathrm{~B})$, where $N A B$ is the number of bands shared by samples, NA represents amplified fragments in sample $\mathrm{A}$, and $N \mathrm{~B}$ represents fragments in sample B. Similarity matrices based on these indices were calculated. 
The similarity co-efficients were then used to construct a dendrogram using the UPGMA (Unweighted Pair-Group Method with Arithmetical average) cluster analysis (Sneath and Sokal, 1973). All procedures were computed with the computer package NTSYSpc (Numerical Taxonomy and Multivariate Analysis System, Biostatistics, New York, USA, software version $2.02 \mathrm{j}$ package) (Rohlf, 1993).

\section{Results and Discussion}

\section{DNA isolation and quantification}

The genomic DNA was successfully isolated from yellow stem borer moths following modified genomic DNA isolation method in our studies. Purification and quantification of genomic DNA isolated from each individual moth was done and fractionated on agarose gel $(0.8 \%)$. The DNA bands of all individuals were intact and did not show any smearing. This reflects good quality DNA preferable for ISSR analysis. The concentration of genomic DNA ranges from $25 \mathrm{ng} / \mu 1$ to $50 \mathrm{ng} / \mu \mathrm{l}$.

\section{ISSR band profile}

Fifty ISSR primers were screened and Eleven ISSR primers were selected on the basis of clarity, usability, and reproducibility of their banding patterns; the data are shown in (Table 2). The 11 primers produced a total of 67 bright and discernible bands, all of which were polymorphic. The number of bands produced by individual primers was in the range of 4-8 (Table 2). The size of the polymorphic bands ranged from $300 \mathrm{bp}$ to $1600 \mathrm{bp}$. The representative banding patterns are shown in Figure 1 and 2 . The primers differed greatly in their potential usability as indicated by the number of scorable amplified bands, e.g. the primer UBC808 and UBC826 produced as many as 8 bands each, while primersUBC812 and UBC873 amplified only 4 bands. Highest number of common bands i.e. 7 bands each was amplified by four primers UBC (AC) 8TC, UBC 811, UBC 856 and UBC 880. Whereas, UBC 864 and UBC 825 amplified six bands each while primer UBC (AC) 8AT amplified five bands. Unique bands of 300bp (Godiapokhari YSB population), 900bp (Sanagaon YSB population) and 1400bp (Sambalpur YSB population) were amplified by the ISSR primers UBC812, UBC811 and UBC812.

\section{ISSR marker performance}

The polymorphic information content varied from $0.264(\mathrm{UBC} 825)$ to 0.368 (UBC873) The highest heterozygosity value $(0.487)$ was obtained with ISSR primer UBC873 and the lowest heterozygosity value (0.255) was observed in ISSR primer UBC856. Whereas the marker index ranged from 1.264 (UBC812) to 2.359 (UBC(AC)8TC). The resolving power (RP) is a parameter that indicates the discriminatory potential of the primers chosen. The highest RP value was observed with the ISSR primer UBC864 (3.778) and the lowest with the ISSR primer UBC856 (1.750) (Table 3).

\section{Dendrogram analysis}

UPGMA clustering method was used to construct the genetic distance matrix. The values of genetic distance ranged from 0.00 to 0.1 , suggesting a great genetic base.

At $20 \%$ level of genetic similarity the sixty YSB populations were grouped into four main clusters. Cluster I consists of 4 YSB populations (Chatia, Diaspatna, Gopinathpur and Sesagaon). Cluster II comprises a maximum of 52 YSB populations. Cluster III has a single YSB population from Balarampur and Cluster IV comprises of three YSB populations i.e. Salepur, Naugada and Soro respectively. 
Table.1 Names of YSB populations along with their latitude and longitude

\begin{tabular}{|c|c|c|c|c|c|c|c|}
\hline $\begin{array}{l}\text { SL } \\
\text { NO }\end{array}$ & PLACE & LATITUDE & LONGITUDE & SL NO & PLACE & LATITUDE & LONGITUDE \\
\hline 1. & Chatia & 20.610352 & 86.060715 & 31 & Khuntuni & 20.565808 & 85.724355 \\
\hline 2. & Gandadhara & 19.925586 & 84.741669 & 32 & Balarampur & 20.674389 & 85.491690 \\
\hline 3. & Sonepur & 20.848014 & 83.895004 & 33 & Chandola & 20.217775 & 86.204840 \\
\hline 4. & Bhola & 20.352135 & 85.723525 & 34 & Mendhasala & 20.267884 & 85.698696 \\
\hline 5. & Pipili & 20.111801 & 85.835287 & 35 & Dhirapur & 20.035385 & 86.010180 \\
\hline 6. & Dolanagar & 20.525678 & 86.261571 & 36 & Nandighora & 20.481750 & 86.264050 \\
\hline 7. & Jijinipur & 20.163763 & 86.055113 & 37 & Sambalpur & 21.466222 & 83.975164 \\
\hline 8. & Maniabandha & 20.440384 & 85.433271 & 38 & Begonia & 20.121211 & 85.272819 \\
\hline 9. & Thengapada & 21.021260 & 84.005319 & 39 & Barahdebta & 21.553116 & 86.440930 \\
\hline 10. & Aruha & 21.315110 & 86.756100 & 40 & Kundeisara & 21.122566 & 84.482847 \\
\hline 11. & Simulia & 20.779435 & 86.750170 & 41 & Manmunda & 20.493593 & 83.551260 \\
\hline 12. & Odagoan & 20.015931 & 84.986955 & 42 & Dardera & 20.123012 & 85.122087 \\
\hline 13. & Diaspatna & 20.045606 & 85.501116 & 43 & Parabil & 21.147450 & 85.157605 \\
\hline 14. & Srikantpur & 20.002488 & 85.541687 & 44 & Narayanpur & 18.958926 & 84.246597 \\
\hline 15. & Hindol & 20.610201 & 85.201073 & 45 & Jagannathpur & 20.241672 & 86.348449 \\
\hline 16. & Danagohiri & 20.145538 & 85.544973 & 46 & Bhootmundei & 20.192750 & 86.344038 \\
\hline 17. & Dadha & 20.404350 & 85.833990 & 47 & Chandaka & 20.368331 & 85.764742 \\
\hline 18. & Kuruda & 18.935649 & 84.220799 & 48 & G.Rambha & 19.516285 & 85.089949 \\
\hline 19. & Teismile & 20.202066 & 86.042890 & 49 & Redhakhol & 21.068382 & 84.335271 \\
\hline 20. & Chianpur & 21.448922 & 87.026396 & 50 & Salepur & 20.481199 & 86.117729 \\
\hline 21. & Nischintkoili & 20.479101 & 86.184712 & 51 & Sanagaon & 20.508985 & 84.960090 \\
\hline 22. & Balipatna & 20.198231 & 85.958554 & 52 & Nuagada Ghati & 20.251188 & 85.202436 \\
\hline 23. & Shrikhandapur & 19.500714 & 85.465942 & 53 & Soro & 21.163581 & 86.431763 \\
\hline 24. & Akhuapada & 20.926156 & 86.288854 & 54 & Sesagaon & 20.291834 & 85.324031 \\
\hline 25. & Ranjisura & 21.222878 & 86.540188 & 55 & Lalitgiri & 20.591630 & 86.264108 \\
\hline 26. & Vellipadia & 21.430947 & 87.043491 & 56 & CRRI & 20.454577 & 85.931646 \\
\hline 27. & Gopinathpur & 20.383672 & 85.372397 & 57 & Kendrapara & 20.500000 & 86.416700 \\
\hline 28. & Godiapokhari & 20.166605 & 85.856464 & 58 & Mangarajpur & 20.767743 & 86.222202 \\
\hline 29. & Indupur & 20.613815 & 86.406746 & 59 & Mallipura & 20.290110 & 86.520845 \\
\hline 30. & Mahanga & 20.559876 & 86.193085 & 60 & Nalanga & 20.038985 & 85.884440 \\
\hline
\end{tabular}

Table.2 Amplification pattern of ISSR primers along with their sequences

\begin{tabular}{|c|c|c|c|c|c|c|c|}
\hline $\begin{array}{l}\text { SI. } \\
\text { No }\end{array}$ & Primer Name & Primer sequence(5'-3') & $\begin{array}{l}\mathrm{Tm} \\
\left({ }^{\circ} \mathbf{C}\right)\end{array}$ & $\begin{array}{l}\text { Band size } \\
\text { range (bp) }\end{array}$ & $\begin{array}{l}\text { No. of } \\
\text { scored } \\
\text { bands }\end{array}$ & $\begin{array}{l}\text { No of } \\
\text { unique } \\
\text { bands }\end{array}$ & $\begin{array}{c}\text { Polymorphic } \\
\text { Bands (\%) }\end{array}$ \\
\hline 1 & UBC (AC)8TC & ACACACACACACACACTC & 53.7 & $400-1000$ & 7 & 0 & $7(100 \%)$ \\
\hline 2 & UBC $808(A G) 8 C$ & AGAGAGAGAGAGAGAGC & 52.8 & $300-900$ & 8 & 0 & $8(100 \%)$ \\
\hline$\overline{3}$ & UBC $811(\mathrm{GA}) 8 \mathrm{C}$ & GAGAGAGAGAGAGAGAC & 52.8 & $300-900$ & 7 & 1 & $7(100 \%)$ \\
\hline 4 & UBC $812(\mathrm{GA}) 8 \mathrm{~A}$ & GAGAGAGAGAGAGAGAA & 50.4 & $300-700$ & 4 & 1 & $4(100 \%)$ \\
\hline$\overline{5}$ & UBC825(AC)8T & ACACACACACACACACT & 50.4 & $500-1000$ & 6 & 0 & $6(100 \%)$ \\
\hline 6 & UBC826(AC)8C & ACACACACACACACACC & 52.8 & $400-1600$ & 8 & 0 & $8(100 \%)$ \\
\hline$\overline{7}$ & UBC856(AC)8CTA & ACACACACACACACACCTA & 54.5 & $600-1450$ & 7 & 0 & $7(100 \%)$ \\
\hline 8 & UBC 864 & ATGATGATGATGATGATG & 46.9 & $500-1000$ & 6 & 0 & $6(100 \%)$ \\
\hline 9 & UBC 873 & GACAGACAGACAGACA & 49.2 & $400-800$ & 4 & 0 & $4(100 \%)$ \\
\hline 10 & UBC 880 & GGAGAGGAGAGGAGA & 50.6 & $300-1400$ & 7 & 1 & $7(100 \%)$ \\
\hline 11 & $\mathrm{UBC}(\mathrm{AC}) 8 \mathrm{AT}$ & ACACACACACACACACAT & 51.4 & $400-800$ & 5 & 0 & $5(100 \%)$ \\
\hline
\end{tabular}


Table.3 ISSR marker performance

\begin{tabular}{|l|c|c|c|c|c|}
\hline SI. No. & Primer Name & $\begin{array}{c}\text { Primer Resolving } \\
\text { power }(\mathbf{R P})\end{array}$ & $\begin{array}{c}\text { Heterozygosity } \\
(\mathbf{H})\end{array}$ & $\begin{array}{c}\text { Polymorphic information } \\
\text { content (PIC) }\end{array}$ & $\begin{array}{c}\text { Marker } \\
\text { index (MI) }\end{array}$ \\
\hline $\mathbf{1}$ & UBC (AC)8TC & 3.639 & 0.429 & 0.337 & 2.359 \\
\hline $\mathbf{2}$ & UBC 808(AG)8C & 3.250 & 0.386 & 0.311 & 2.488 \\
\hline $\mathbf{3}$ & UBC 811(GA)8C & 2.806 & 0.365 & 0.298 & 2.086 \\
\hline $\mathbf{4}$ & UBC 812(GA)8A & 1.806 & 0.394 & 0.316 & 1.264 \\
\hline $\mathbf{5}$ & UBC 825(AC)8T & 1.944 & 0.313 & 0.264 & 1.584 \\
\hline $\mathbf{6}$ & UBC 826(AC)8C & 3.139 & 0.355 & 0.292 & 2.336 \\
\hline $\mathbf{7}$ & UBC856(AC)8CTA & 1.750 & 0.255 & 0.222 & 1.554 \\
\hline $\mathbf{8}$ & UBC 864 & 3.778 & 0.470 & 0.359 & 2.154 \\
\hline $\mathbf{9}$ & UBC 873 & 2.806 & 0.487 & 0.368 & 1.472 \\
\hline $\mathbf{1 0}$ & UBC 880 & 2.556 & 0.342 & 0.283 & 1.981 \\
\hline $\mathbf{1 1}$ & UBC (AC)8AT & 3.417 & 0.483 & 0.366 & 1.83 \\
\hline
\end{tabular}

Fig.1 Amplification pattern with ISSR primer UBC 808

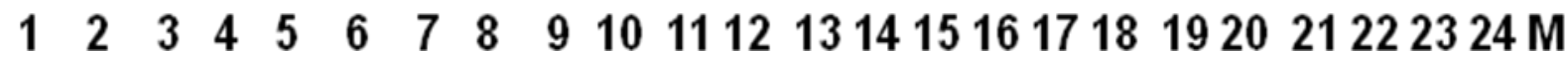

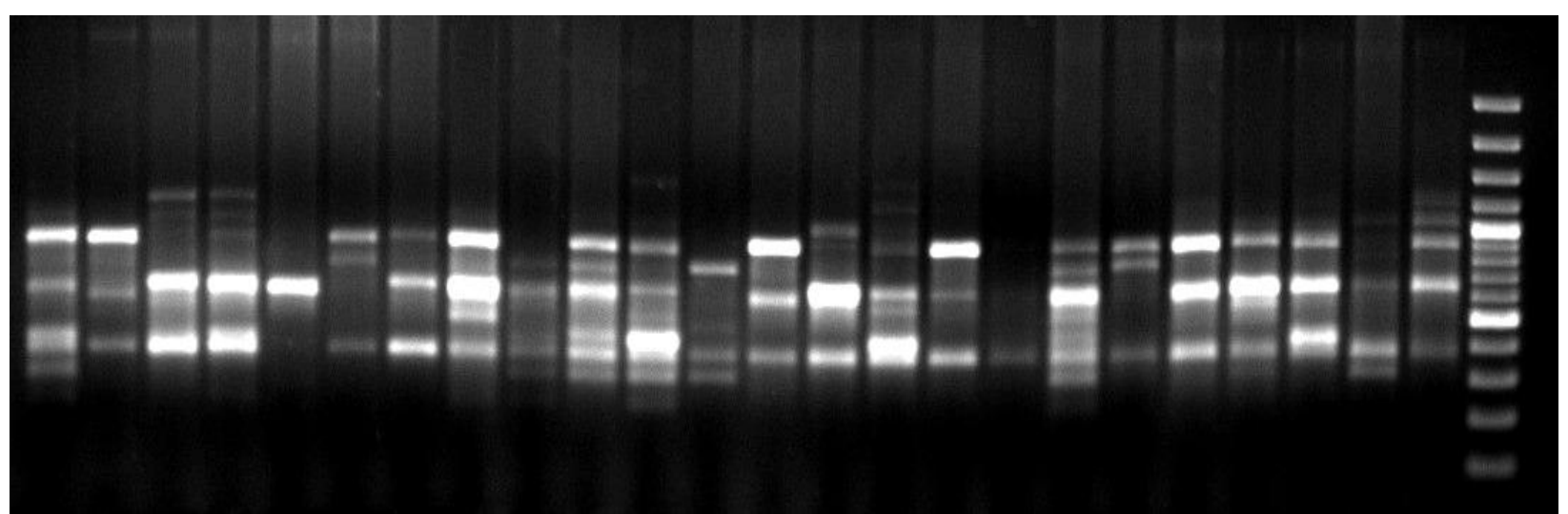

Numbers above the lanes indicate the YSB populations $\mathrm{M}=100 \mathrm{Base}$ pair DNA Ladder

Fig.2 Amplification pattern with ISSR primer UBC 864

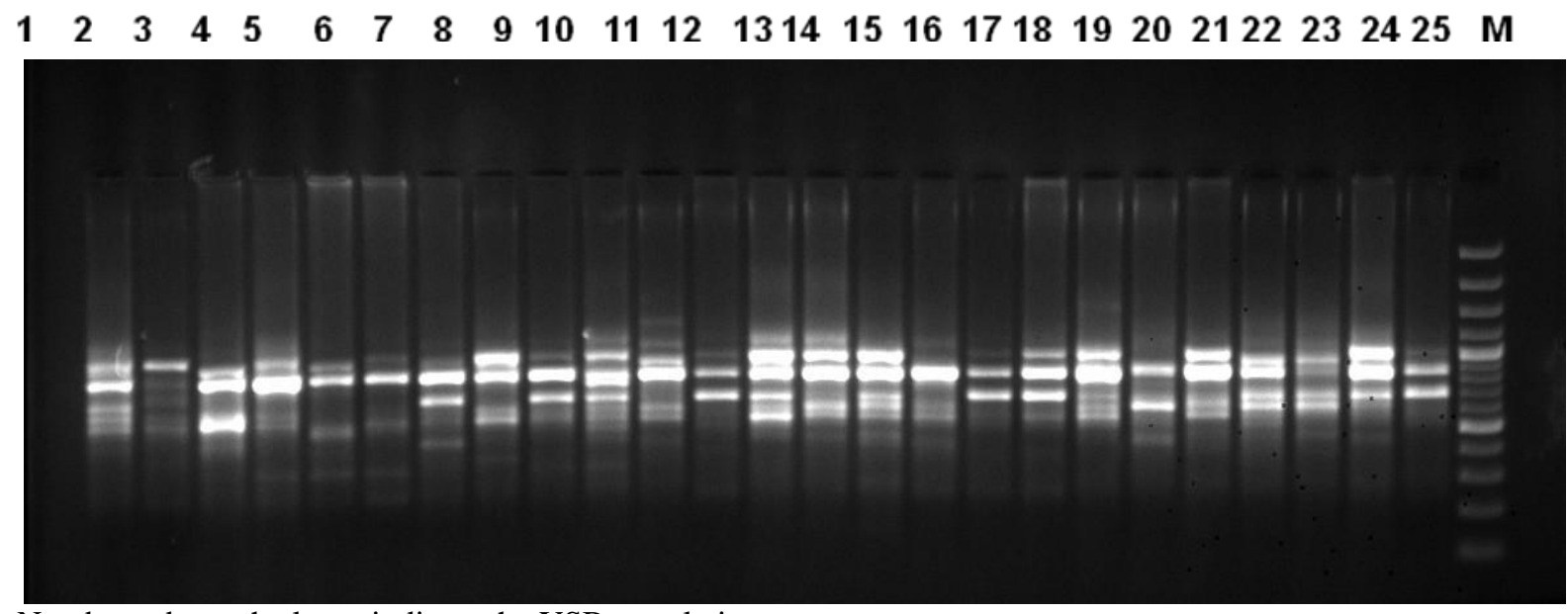

Numbers above the lanes indicate the YSB populations 
Fig.3 Dendrogram showing genetic relationship among YSB populations based on loci amplified by ISSR primer

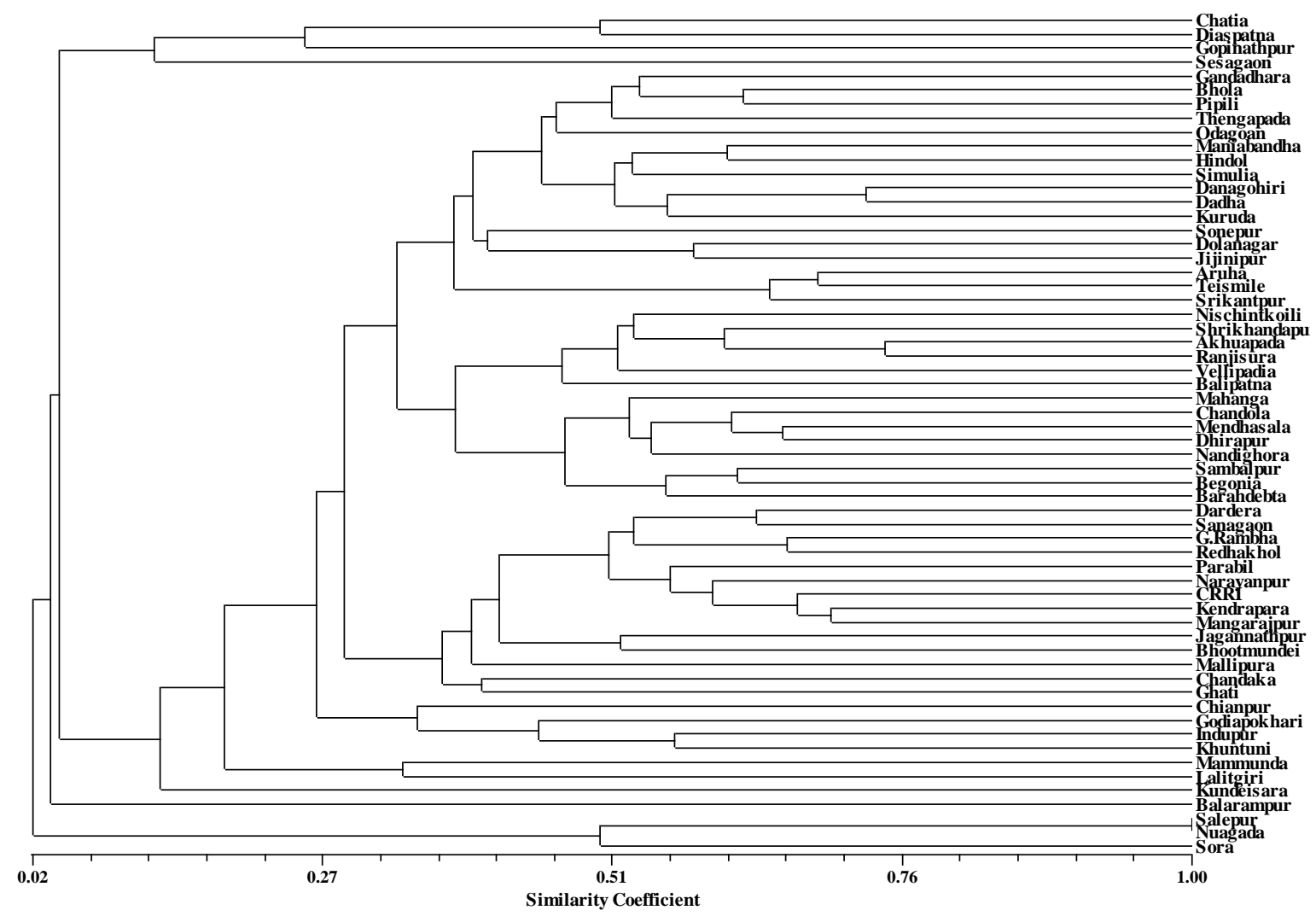

The second major cluster II comprising of 52YSB populations is further sub-divided into four Sub clusters i.e., A, B, C and D. Sub cluster A consists of 31YSB populations (Gandadhara, Sonepur, Bhola, Pipili, Dolanagar, Jijinipur, Maniabandha, Thengapada, Aruha, Simulia, Odagoan, Srikantpur, Hindol, Danagohiri, Dadha, Kuruda, Teismile, Nischintkoili, Shrikhandapur, Akhuapada, Ranjisura, Vellipadia, Balipatna, Mahanga, Chandola, Mendhasala, Dhirapur, Nandighora, Sambalpur, Begonia and Barahdebta). The subcluster B comprises of 14YSB populations (Dardera, Sanagaon, G.Rambha, Redhakhol, Parabil, Narayanpur, NRRI, Kendrapara, Mangarajpur, Bhootmundei, Jagannathpur, Mallipura, Chandaka and Ghati) and subcluster $\mathrm{C}$ and $\mathrm{D}$ consists of four (Chianpur, Godiapokhari, Indupur, khuntuni) and three (Manmunda, Lalitgiri, Kundeisara) YSB populations respectively (Fig. 3).

In the present study, modified method of DNA isolation was found to be suitable for extraction of good quality and high molecular weight genomic DNA from adult female. ISSR technique was found efficient enough to reveal usable level of DNA polymorphism among adult females.

As ISSR-PCR DNA fingerprinting method targets random SSR or microsatellites, it has been used extensively to uncovering species level divergences and also a good tool for distinguishing geographic populations (Zietkiewicz et al., 1994). In present study, among 50 ISSR primers screened only eleven ISSR primers were found polymorphic. All primers successfully amplified a total of 67 
reproducible polymorphic bands. The size of bands varied from $300 \mathrm{bp}$ to $1600 \mathrm{bp}$. Mohammad Javad Ardeh (2013) studied the utility of ISSR-primers to make difference among populations of parasitoid, Eretmocerus mundus mercet (hymenoptera: aphelinidae). From 60 ISSR primers, checked, 64 bands were obtained from 16 primers. The bands size ranged from above 200 to $1000 \mathrm{bp}$ for different primers. The rate of divergence among the bands was strong enough to make a clear cut difference among the studied specimens. Three unique loci were identified which could be developed into diagnostic markers to identify particular population of YSB. Genetic similarity among YSB populations ranged from 0.00 to 0.1 , revealing wide genetic variation among YSB populations. Cluster analysis based on UPGMA, dendrogram grouped all the 60 populations of YSB into four different major groups corresponding to their geographical location. Velu et al., (2008) used ISSR markers to determine genetic relationships among mutant silkworm strains of Bombyx mori. The dendrogram produced using the unweighted pair group method with arithmetic means (UPGMA) and cluster analysis made using Nei's genetic distance resulted in the formation of one major group containing 6 groups separated 20 mutant silkworm strains. Similar to our study, Kumar et al., (2001) used ISSR markers to assess the genetic diversity of 28 YSB populations collected from different hotspots of India. They used 9 ISSR primers which gave rise to 79 amplification products of which 67 were polymorphic. A dendrogram constructed from this data indicates that there is no geographical bias to the clustering and that gene flow between populations appears to be relatively unrestricted. Liu et al., (2010) employed inter-simple sequence repeat (ISSR) markers to investigate the genetic diversity and differentiation of 47 populations of white backed planthopper, Sogatella furcifera (Hemiptera: Delphacidae) sampled from 14 prefectures of the Greater Mekong Subregion. A total of 14 selected primers yielded 121 bright and discernible bands, with an average of 8.6 bands per primer. NeighborJoining cluster analysis of the 47 populations showed two major clusters, one consisting of mostly southwestern Yunnan Province and Myanmar populations; and the other one consisting of southeastern and central of Yunnan Province plus Vietnam and Laos populations. NIE et al., (2012) used eight different inter simple sequence repeat (ISSR) markers as tools to investigate genetic variability and population differentiation in the Chinese alligator, Alligator sinensis. Eleven polymorphic bands (17.2\%) out of a total of 64 were generated from 110 individuals in three populations. Analysis of molecular variation showed that most of the genetic variation $(98.0 \%)$ occurred within the populations.

In conclusion, the ISSR markers gave complete, very reliable, reproducible and highly polymorphic fingerprints among populations of yellow stem borers. The present study reveals that PCR based fingerprinting techniques (ISSR) are informative for estimating the extent of genetic diversity as well as determining the pattern of genetic relationships among yellow stem borer populations from different regions of Odisha, India. In future, more number of ISSR markers should be used to study genetic relationships among more species and generas so that the most abundant SSR motifs can be identified and developed into microsatellite markers

\section{Acknowledgement}

We gratefully acknowledge the help and financial support provided by the Director, Central Rice Research Institute, Cuttack, India. 


\section{References}

Anonymous 1993. Isolation of high molecular weight DNA from a single insect. Workshop on molecular biology of malaria vectors, Madras, India.

Bandong, J.P., and J.A. Litsenger. 2005. Rice crop stage susceptibility to the rice yellow stemborer Scirpophagain certulas (Walker). Int. J. Pest Manage. 51(1): 3743.

Bornet, B., F. Goraguer, G. Joly \& M. Branchard, 2002. Genetic diversity in European and Argentinian cultivated potatoes (Solanum tuberosum subsp. tuberosum) detected by inter-simple sequence repeats (ISSRs). Genome 45(3): 481-484.

Israel, P. and Padmanabhan, S.Y. 1976. Biology and Control of Stem Borers of Rice in India Final Technical Report. CRRI, Cuttack, India.

Khan, Z.R., Litsinger, J.A., Barrion, A.T., Villanueva, F.F.D., Fernandez, N.J., Taylo, L.D., 1991. World Bibliography of Rice Stem Borers, vol. 415. Center of Insect Physiology and Ecology, International Rice Research Institute, Los Banos, Philippines, pp. 1794-1990.

Li, M.W., C.X. Hou, X.X. Miao, A.Y. Xu and Y.P. Huang, 2007. Analyzing genetic relationship in Bombyx mori using inter simple sequence repeat amplification. J. Economic Entomol., 100: 202-208.

Lv, J., L.T. Wilson, and M.T. Longnecker. 2008. Tolerance and compensatory response of rice to sugarcane borer injury". Environ. Entomol. 37: 796-807.

Muralidharan, K., and I.C. Pasalu. 2006. Assessments of crop losses in rice ecosystem due to stem borer damage. Crop Prot. 25: 409-417.

Nagy S, Poczai. P, Cernak I, Gorji AM, Hegedus G, Taller J. 2012. PIC calc: An Online Program to Calculate Polymorphic Information Content for Molecular Genetic Studies Biochem Genet 50:670672.

Prevost A, Wilkinson MJ. 1999. A new system of comparing PCR Primers applied to ISSR fingerprinting of potato cultivars. Theoretical and applied Genetics, 98(1): 107-112.

Reddy KD, Abraham EG, Nagaraju J. 1999b. Microsatellites of the silkworm, Bombyx mori: abundance, polymorphism and strain characterization. Genome 42: 10571065.

Rohlf FJ (1993) NTSYS-pc (Numerical Taxonomy and Multivariate Analysis System), version 2.11. Exeter Software, Setauket.

Sneath, P.H.A., Sokal, R.R. 1973. Numerical taxonomy. W.H. Freeman and Company, San Francisco. 147-157.

Vijayan K, Anuradha HJ, Nair CV, Pradeep AR, Awasthi AK, et al., (2006) Genetic diversity and differentiation among populations of the Indian eri silkworm, Samia cynthia ricini, revealed by ISSR markers. J Insect Sci 6: 1-11.

Wolfe, A.D., Q-Y. Xiang \& S.R. Kephart, 1998. Diploid hybrid speciation in Penstemon (Scrophulariaceae). Proc Natl Acad Sci USA 95: 5112-5115.

Zietkiewicz E, Rafalski A, Labuda D. 1994. Genome fingerprinting by simple sequence repeat (SSR) - anchored polymerase chain reaction amplification. Genomics 20: 176-183.

\section{How to cite this article:}

Rudraksh Shovan Panda, Lambodar Behera and Sarat Chandra Sahu. 2018. Genetic Diversity among Rice Yellow Stem Borer, Scirpophaga incertulas Revealed Using ISSR Markers. Int.J.Curr.Microbiol.App.Sci. 7(04): 123-131. doi: https://doi.org/10.20546/ijcmas.2018.704.014 